\title{
A Building Information Modelling (BIM) based Water Efficiency (BWe) Framework for Sustainable Building Design and Construction Management
}

\author{
Zhen Liu ${ }^{1}$, Chao Zhang ${ }^{2, *}$, Yuanxiang Guo ${ }^{3}$, Mohamed Osmani ${ }^{4}$ and Peter Demian ${ }^{4}$ \\ 1 School of Design, South China University of Technology, Guangzhou 510006, China; liuzjames@scut.edu.cn \\ 2 School of Civil Engineering and Transportation, South China University of Technology, \\ Guangzhou 510641, China \\ 3 Architectural Design and Research Institute, South China University of Technology, \\ Guangzhou 510641, China; gzchgd@126.com \\ 4 School of Architecture, Building and Civil Engineering, Loughborough University, \\ Loughborough LE11 3TT, UK; m.osmani@lboro.ac.uk (M.O.); P.Demian@lboro.ac.uk (P.D.) \\ * Correspondence: ctzhangchao@mail.scut.edu.cn; Tel.: +86-20-3938-0726
}

Received: 28 April 2019; Accepted: 24 May 2019; Published: 29 May 2019

\begin{abstract}
There is a lack of decision-making tools for water efficiency design and construction to maximize project benefits and water conservation. An increasing number of research studies indicate that building information modelling (BIM) can enhance the cooperation, improve work efficiency, and conduct simulation and analysis of sustainability performance in building projects. However, BIM's potential to enhance water efficiency is yet to be established, such as water gird design optimization, clash detection, combination of BIM with smart appliances and sensors. The research adopted a mixed method approach to investigate the potential impact of BIM on water efficiency in building projects. It involved 50 practitioners from the Architectural, Engineering and Construction (AEC) industry through a questionnaire survey and the follow-up interviews. The quantitative results of questionnaire data and qualitative results of interviews were used to develop a "BIM-based Water Efficiency (BWe) Framework" which was subsequently validated by five experienced practitioners and researchers in the form of semi-structured interviews. The framework applies BIM to optimize traditional water efficiency measures based on an information database. The geometry, attributes, status information of building components or non-component objects stored in the database greatly improve information integration degree of construction engineering. This study provided a reference for the use of BIM for water conservation in building design and construction.
\end{abstract}

Keywords: building information modelling (BIM); sustainable building design; rating system; construction water efficiency

\section{Introduction and Literature Review}

There are various green building rating systems providing guidance for building water efficiency around the world, indicating that water efficiency as an important sustainability performance has been increasingly emphasized. However, there is still a lack of decision-making tools supporting water efficiency design and construction. A tool for integrating building information, building information modelling (BIM) has been verified to enhance green building construction activities. Its potential for water efficiency is yet to be studied. 


\subsection{Water Efficiency Issues in Green Building Rating Systems}

Green building rating systems require an integrated design process to create buildings that are resource-efficient throughout their life-cycle. A large number of green rating systems have been established to help mitigate these impacts through the encouragement, measurement and recognition of sustainability performance. These include global schemes such as LEED (Leadership in Energy and Environmental Design) [1,2], BREEAM (Building Research Establishment Environmental Assessment Method) [3-5], and some regional schemes such as Green Mark [6,7], BEAM (Building Environmental Assessment Method) Plus [8,9], China's Assessment Standard for Green Building GBT50378-2014 [10]. They contain water efficiency credits for indoor use, outdoor use, specialized uses, and metering.

The comparison of water efficiency credits among the mentioned rating systems is shown in Table 1 [1-10].

Table 1. Water efficiency comparison among different rating systems.

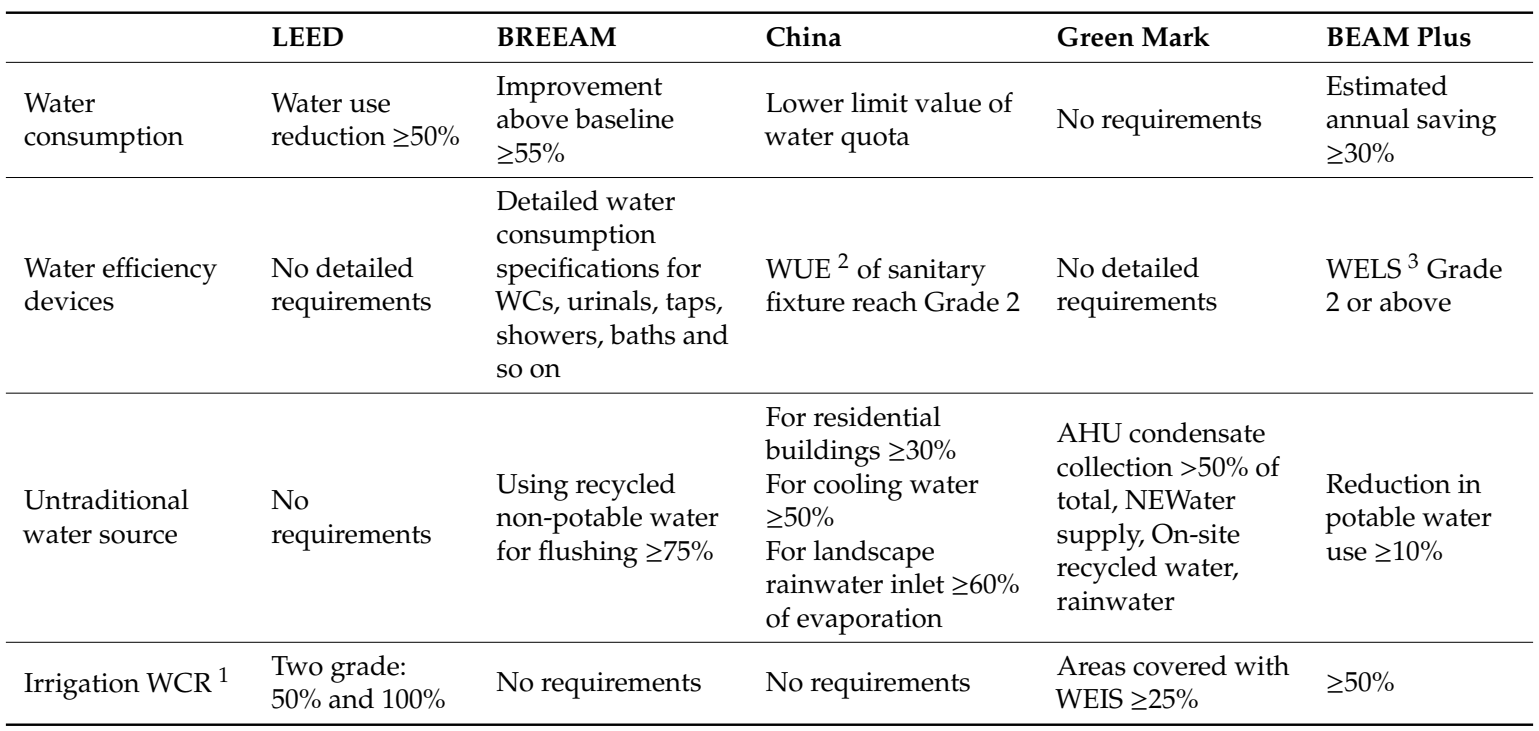

${ }^{1}$ WCR-Water conservation rate. ${ }^{2}$ WUE-Water use efficiency. ${ }^{3}$ WELS-Water efficiency labelling Scheme.

LEED emphasizes the overall performance of a building to fulfil the green building design and construction requirements rather than setting rigid targets [11]. Detailed numerical values and measures to reach water efficiency targets are defined to assess the performance. For example, to get a top score in water consumption, water use should be reduced by over $50 \%$. On the other hand, detailed BREEAM specifications for flow rate of water consumption components such as WCs, urinals, taps, showers, baths, dishwasher and washing machine are defined to manage water use, monitoring and management. In populous areas, BREEAM calls for a more reasonable water use structure with reducing potable water demand for irrigation or flushing, which can be achieved by alternative water sources. Therefore, China's rating system, Green Mark and BEAM Plus set bespoke evaluation alternatives for unconventional water sources such as rainwater harvesting and recycled grey water.

\subsection{Building Information Modelling (BIM) for Green Building}

BIM represents a change of the traditional way of building design, construction and management. Its adoption rate in the US AEC industry has increased from $17 \%$ in 2007 to $71 \%$ in 2012 [12], while in the UK it has risen to $74 \%$ in 2018 [13]. At present, BIM is gradually used to achieve various architectural design, construction, and facility management performance objectives, including improving simulation and analysis function, communication and coordination, and message evaluation throughout the entire life cycle of buildings [14]. 
The basic characteristics of BIM can be summarized in four aspects: Integrating with various databases; facilitating document management; visualizing the analysis process and results; and providing sustainability analysis and simulation [15]. BIM provides a platform for information exchange, and thereby has the potential strengthening collaboration and communication among all related parties involved in collaborative works [16]. In the design stage, BIM allows for the simulation of sustainability performance such as analysis of heating ventilation air conditioning and indoor illumination energy consumption [17], simulation of sunlight and solar energy applications [18] and simulation of water use [15], thereby achieving more reliable design. In the construction stage, BIM 3-D visualization management assists construction technicians to conduct conflict detection and arrange construction organization planning more rationally [19]. While in the operation stage, BIM provides a reliable database integrating early-stage building information into the operation stage and ensuring the storage and updating of new data generated during the operation stage [20].

With the development of green buildings, many researchers and early adopters of BIM for green buildings have increasingly applied BIM for energy simulation and lighting analysis. Chen and Pan [21] developed a BIM-aided decision-making model for selecting low-carbon building measures, aiming to improve the robustness and practicality of decision results over traditional methods. Lim YW. et al. [22] proposed a sustainable BIM-based design framework which integrates BIM into the functional targets of sustainability design, including thermal performance, visual performance and energy efficiency. Olawumi and Chan [23] identified the leading benefits of integrating BIM and sustainability practices, including the ability to simulate building performances and energy usage. However, few researchers and BIM users have applied BIM to other aspects of green building evaluation, such as the building water saving model analysis [24].

\subsection{BIM's Potential for Water Efficiency}

A recent BIM Guidance for the Water Industry report [25] concludes the benefits of BIM including Water Industry service measures; customer and operation. In addition, it provides Water Industry practitioners with guidance on some broad interpretation of PAS1192 [26] (a British standard for information management) and their equivalents within the water industry, such as organization information and asset information requirements. However, this report does not focus on the operational process of applying BIM to water efficiency throughout design, construction and operation stages during a construction project, which is the tentative discussion in this study.

Bonenberg and Wei [18] used BIM tools to simulate rainwater harvesting and water circulation systems during the design phase, a case of tent-shaped roof was used to collect rainwater which was stored in a large water storage space under the ground and the collected rainwater was used for irrigation or other energy efficiency measures. Bernstein et al. [24] argued that the Shanghai Tower in China applied BIM during the design stage to assist in the design of special curtain wall structure thereby reducing high-rise building wind loads and improving rainwater harvesting. Lu and Wu et al. [15] pointed out that BIM mainly supported water consumption analysis during the design phase. As such, the BIM software assisted in optimizing the water distribution system of buildings. Wong et al. [27] summarized the different ways by which BIM could help plan and design building sustainability and concluded that the benefits of BIM included investigating the potential for catchment water to reduce water demand for buildings. Martins et al. [28] developed a method and a software application for the automated code-checking of building water network designs. Edmondson et al. [29] proposed a smart sewerage asset information model (SSAIM), using open BIM data standards to facilitate data exchange during the operation stage. Motawa et al. [30] argued that the application of BIM in the operation stage of a building could assist in managing and controlling resources such as electricity, water and gas. Wei et al. [31] considered a combination of BIM with LEED rating system and developed a water efficiency design process. Five steps were contained in this process: LEED strategy and BIM execution plan; conceptual design; design criteria; detailed design; implementation; and documentation. On the other hand, Jia et al. [32] applied BIM to check the water supply, sewage 
and rainwater pipes during the construction stage. Howell et al. [33] united BIM, smart appliances, intelligent sensing and cybernetics to save cost and water resource throughout building life cycle stages (design, construction and operation). Ahuja et al. [34] reported that using BIM in the design process can reduce water consumption, and through surveys in the study, there is a $28 \%$ chance of using the MEP system to achieve lean and green results. These related researches are summarized in Table 2 that contains the various research methods they adopted and different building life cycle stages to which their results were applied.

Table 2. The current use of BIM in water efficiency research.

\begin{tabular}{|c|c|c|c|c|}
\hline \multirow{2}{*}{ Author } & \multirow{2}{*}{ Research Method } & \multicolumn{3}{|c|}{ Building Life Stage } \\
\hline & & Design & Construction & Operation \\
\hline Bonenberg et al. [18] & Case Study & $\sqrt{ }$ & & \\
\hline Bernstein et al. [24] & Case Study & $\sqrt{ }$ & & \\
\hline Lu et al. [15] & Literature Review & $\sqrt{ }$ & & \\
\hline Wong et al. [27] & Literature Review & $\sqrt{ }$ & & \\
\hline Martins et al. [28] & Modelling & $\sqrt{ }$ & & \\
\hline Edmondson et al. [29] & Modelling & & & $\sqrt{ }$ \\
\hline Motawa et al. [30] & Framework & & & $\sqrt{ }$ \\
\hline Wei et al. [31] & $\begin{array}{l}\text { Framework and Fuzzy } \\
\text { comprehensive Evaluation }\end{array}$ & $\sqrt{ }$ & & \\
\hline Jia et al. [32] & Survey Analysis & & $\sqrt{ }$ & \\
\hline Howell et al. [33] & Data Analysis & $\sqrt{ }$ & $\sqrt{ }$ & $\sqrt{ }$ \\
\hline Ahuja et al. [34] & $\begin{array}{l}\text { Crisp Set Qualitative } \\
\text { Comparative Analysis }\end{array}$ & $\sqrt{ }$ & & \\
\hline
\end{tabular}

However, most of those studies only provide assumptions or partial water efficiency simulation analysis. No research has attempted to explore how to apply BIM to multiple stages of a construction project to maximize project benefits and water efficiency. Other researches also point out four main factors hindering the application of BIM in green building: Technical (poor adaptability of BIM technology, high technical difficulty and BIM software is still in progress) $[12,31,35,36]$; human (lack of BIM talent, lack of the structure of knowledge and ability, and rely on traditional methods) [20,27]; economic (high short-term cost, long payback period, and untapped BIM market) [16,37,38]; management (difficulties in managing change and business process transformation, and low acceptance in management) [15,37]. To better guide BIM's application for water efficiency and clear further related research, it is necessary to analyze BIM's advantages in water efficiency and development obstacles.

This study sets out to address the integration of BIM and building water efficiency to achieve informed decisions on water saving and monitoring. The research culminates in the development of a stakeholder to integrate water efficiency across a building life cycle stages.

\section{Materials and Methods}

A mixed research method was used in this research to develop a BIM-based sustainable water efficiency design framework and proposes pathways for future research in the field. The adopted methodology is twofold: A questionnaire survey and follow-up semi-structured interviews. The sustainable building design and construction management is taken as the research object, to which architects contribute significantly. Therefore, 50 architectural companies have been randomly selected as a sample for this study in order to capture the architectural practitioners' opinions on the potential of applying BIM to water efficiency. Overall, 23/50 questionnaires were returned, and the distribution 
is shown in Figure 1. The collected data was used to verify the potential of applying BIM to save water by using the combined method of variance analysis and hypothesis testing in SPSS V25.

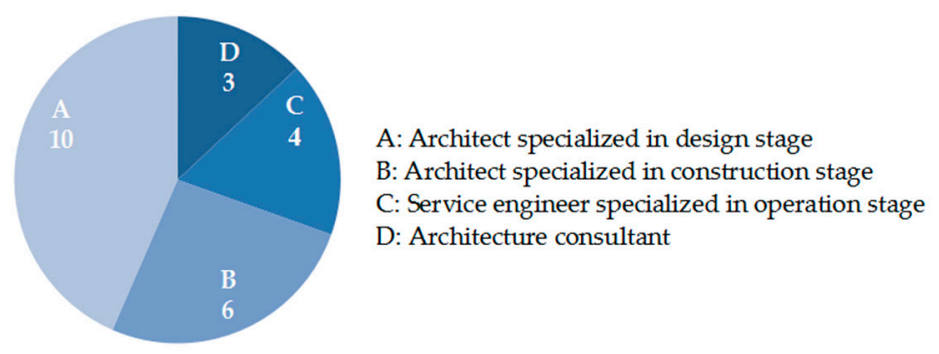

Figure 1. Distribution of 23 valid data.

The quantitative results were used as basis for a follow-up investigation through six semi-structured interviews to investigate further the relationship between BIM and building water efficiency. Interviews focus on other BIM-enhanced construction activities not included in the questionnaire and respondents' suggestions on better application of BIM in water efficiency. These six interviewees were selected according to their willingness expressed in the questionnaire, and the distribution was shown in Table 3.

Table 3. Distribution of six interviewees.

\begin{tabular}{cc}
\hline Interviewees' Code & Organization \\
\hline A & Architect specializing in design stage \\
B & Architect specializing in design stage \\
C & Architect specializing in construction stage \\
D & Service engineer specializing in operation stage \\
E & Service engineer specializing in operation stage \\
F & Architecture consultant \\
\hline
\end{tabular}

Integrating the outcomes of literature review, quantitative analysis of questionnaire data and qualitative analysis of the interviews, a preliminary BIM-based building water efficiency framework (BWe framework) and a conceptual algorithm with a summation formula are proposed. The framework and formula were subsequently industry reviewed via a validation questionnaire survey and the semi-structured interview involved five participants from the respondents of the early questionnaire.

\section{Analysis and Results}

\subsection{The Potential of BIM to Solve Common Problems During the Execution of Construction Projects}

The questionnaire instruments listed problems reported in the literature, such as project losses since confused drawings, ineffective design, failure to achieve performance target due to data loss during information transfer, rework, ineffective management and weak management awareness. Questionnaire respondents were asked to indicate whether they have encountered those problems during a construction project based on their own engineering experience. According to whether the respondents have been confronted with those problems, respondents are divided into two groups: Group A and Group B (Group A = have encountered problems, and Group B = never encountered problems). Subsequently, the potential of applying BIM to solve those problems is evaluated using a scale of $1-4(1=$ No potential, $2=$ Low potential, $3=$ Medium potential, $4=$ High potential $)$. Differences in perceptions of the potentials among the two groups of professionals were tested for their statistical significance using analysis of variance (ANOVA) methods.

The analysis results are shown in Table 4. The ANOVA indicates that under specific problem conditions (such as project or investment losses caused by unclear and confused drawings, ineffective 
design due to inadequate communication between different professionals, incoherent design due to various interventions, failure to achieve performance target due to data loss during information transfer, problems such as rework caused by design change, ineffective management due to overdependence on manpower, weak management awareness), the value of significance (Sig.) $>0.05$, indicating that there is no statistically significant difference in the judgment of the potential of BIM between Group A and Group B. To explain further, whether professionals have ever encountered those problems in their project experiences have no effect on their judgments about BIM's potential. A single sample $t$-test was applied for all 23 sets of data. A $95 \%$ confidence interval of the difference is adopted to predict the potential of BIM to address the problem, when the lower limit value of potential is greater than 2.00 (BIM has low potential to address the problem), it is considered that BIM does have the potential to solve the problem.

\subsection{The Potential of BIM for Building Water Efficiency at Various Stages}

Questionnaire respondents were asked to evaluate on a Likert scale 1-4 the potential of BIM for water efficiency during design, construction and operation stages $(1=$ No potential, $2=$ Low potential, $3=$ Medium potential, $4=$ High potential). The architecture consultant usually provides consulting services of related professional knowledge and technology throughout the entire building life cycle, therefore architects specializing in design stage and architecture consultants are the major participants to develop the water efficiency model during the design stage, while architects specializing in construction and service engineers specializing in the operation stage are not. The respondents for water efficiency measures during the design stage are divided into Group A1 and Group B1 (Group A1 = architects specializing in the design stage and architecture consultants, Group B1 = architects specializing in construction and service engineers specializing in the operation stage) in order to eliminate the gap caused by professionals who are responsible for different building stages. Similarly, the respondents for water efficiency measures during the construction stage are divided into Group A2 and Group B2 (Group A2 = architects specializing in the construction stage and architecture consultants, Group B2 = architects specializing in design and service engineers specializing in the operation stage). The respondents for water efficiency measures during the operation stage are divided into Group A3 and Group B3 (Group A3 = service engineers specializing in the operation stage and architecture consultants, Group B3 = architects specializing in the design and construction stage).

Differences in perceptions of the potentials among the different groups of professionals were tested for their significance using ANOVA. The analysis results are shown in Table 5. The value of significance (Sig.) $>0.05$ for most measures such as rainwater harvesting and water circulation system simulation, water consumption analysis and catchment potential investigation during the design stage; optimization of the water grid design; water supply, sewage and rainwater pipes checks during the construction stage; simplification of repetitive and needless construction process; and real-time monitoring of water resource, and combination of BIM with smart appliances and smart sensors during the operation stage. There is no statistically significant difference in the judgment of potential between the groups. A single sample $t$-test was applied for all 23 data points. A $95 \%$ confidence interval of the difference is adopted to predict the potential of BIM for building water efficiency, when the lower limit value of potential is greater than 2.00 (BIM has low potential for building water efficiency), it is considered that BIM does have the potential to enhance these water efficiency items. 
Table 4. The potential of BIM to solve common problems (questionnaire's responses).

\begin{tabular}{|c|c|c|c|c|c|c|c|c|c|c|c|c|c|}
\hline \multirow{3}{*}{$\begin{array}{l}\text { Groups of Being } \\
\text { Confronted with } \\
\text { Specified Problem }\end{array}$} & \multicolumn{4}{|c|}{ Group Statistics } & \multirow{3}{*}{ Problem } & \multicolumn{2}{|c|}{$\begin{array}{c}\text { Analysis of } \\
\text { Variance }\end{array}$} & \multicolumn{6}{|c|}{ Single Sample $t$-test for All 23 Data } \\
\hline & \multirow[t]{2}{*}{$\mathbf{N}$} & \multirow[t]{2}{*}{ Mean } & \multirow{2}{*}{$\begin{array}{l}\text { Std. } \\
\text { Deviation }\end{array}$} & \multirow{2}{*}{$\begin{array}{l}\text { Std. } \\
\text { Error } \\
\text { mean }\end{array}$} & & \multirow[t]{2}{*}{$\mathbf{F}$} & \multirow[t]{2}{*}{ Sig. } & \multirow[t]{2}{*}{ Mean } & \multirow[t]{2}{*}{$t$} & \multirow{2}{*}{$\begin{array}{c}\text { Std. } \\
\text { Deviation }\end{array}$} & \multirow{2}{*}{$\begin{array}{l}\text { Std. } \\
\text { Error } \\
\text { Mean }\end{array}$} & \multicolumn{2}{|c|}{$\begin{array}{l}\text { 95\% Confidence } \\
\text { Interval of the } \\
\text { Difference }\end{array}$} \\
\hline & & & & & & & & & & & & Lower & Uppe \\
\hline Yes (Group A) & 15 & 3.13 & 1.060 & 0.274 & \multirow{2}{*}{$\begin{array}{c}\text { losses caused by unclear and confused } \\
\text { drawings }\end{array}$} & \multirow{2}{*}{0.082} & \multirow{2}{*}{0.777} & \multirow{2}{*}{3.09} & \multirow{2}{*}{14.226} & \multirow{2}{*}{1.041} & \multirow{2}{*}{0.217} & \multirow{2}{*}{2.64} & \multirow{2}{*}{3.54} \\
\hline No (Group B) & 8 & 3.00 & 1.069 & 0.378 & & & & & & & & & \\
\hline Yes (Group A) & 16 & 3.44 & 0.814 & 0.203 & \multirow{2}{*}{$\begin{array}{l}\text { Ineffective design due to communication } \\
\text { between different professionals }\end{array}$} & \multirow{2}{*}{0.176} & \multirow{2}{*}{0.679} & \multirow{2}{*}{3.39} & \multirow{2}{*}{20.779} & \multirow{2}{*}{0.783} & \multirow{2}{*}{0.163} & \multirow{2}{*}{3.05} & \multirow{2}{*}{3.73} \\
\hline No (Group B) & 7 & 3.29 & 0.756 & 0.286 & & & & & & & & & \\
\hline Yes (Group A) & 14 & 2.64 & 1.008 & 0.269 & Ineffective decion for various interyentions & & & & & & & & \\
\hline No (Group B) & 9 & 2.67 & 0.866 & 0.289 & Ineffective design for various interventions & 0.003 & 0.954 & 2.65 & 13.609 & 0.935 & 0.195 & 2.25 & 3.06 \\
\hline Yes (Group A) & 12 & 3.08 & 0.668 & 0.193 & Data loss during information transfer & 0094 & 0760 & & 2076 & 0620 & & & 232 \\
\hline No (Group B) & 11 & 3.00 & 0.632 & 0.191 & Data loss during information transter & 0.094 & 0.762 & 3.04 & 22.876 & 0.638 & 0.133 & 2.77 & 3.32 \\
\hline Yes (Group A) & 15 & 2.93 & 1.100 & 0.284 & Problems such as rework caused by & 0014 & 0005 & 201 & 12004 & 1002 & (200 & 24 & 220 \\
\hline No (Group B) & 8 & 2.88 & 1.126 & 0.398 & design change & 0.014 & 0.905 & 2.91 & 12.894 & 1.083 & 0.226 & 2.44 & 3.38 \\
\hline Yes (Group A) & 11 & 2.55 & 0.934 & 0.282 & Oyerdenendence on mannower & 0002 & 0776 & 261 & 12660 & 0000 & 0206 & 210 & 204 \\
\hline No (Group B) & 12 & 2.67 & 1.073 & 0.310 & Uveraependence on manpower & 0.083 & 0.776 & 2.61 & 12.662 & 0.998 & 0.206 & 2.18 & 3.04 \\
\hline Yes (Group A) & 13 & 2.23 & 0.832 & 0.231 & Weak manacoment awareness & 0008 & 0920 & 220 & 12372 & 0705 & 01666 & 187 & 256 \\
\hline No (Group B) & 10 & 2.20 & 0.789 & 0.249 & velak mantagement awareness & 0.008 & 0.929 & 2.22 & $13.3 / 2$ & 0.795 & 0.166 & 1.87 & 2.56 \\
\hline
\end{tabular}


Table 5. The potential of BIM for building water efficiency at various stages (questionnaire's responses).

\begin{tabular}{|c|c|c|c|c|c|c|c|c|c|c|c|c|c|}
\hline \multirow{3}{*}{$\begin{array}{l}\text { Groups of } \\
\text { Different } \\
\text { Units }\end{array}$} & \multicolumn{4}{|c|}{ Group Statistics } & \multirow{3}{*}{$\begin{array}{c}\text { Potential Application of BIM in Water } \\
\text { Efficiency }\end{array}$} & \multicolumn{3}{|c|}{$\begin{array}{l}\text { Analysis of } \\
\text { Variance }\end{array}$} & \multicolumn{5}{|c|}{ Single Sample t-test for All 23 Data } \\
\hline & \multirow[t]{2}{*}{$\mathbf{N}$} & \multirow[t]{2}{*}{ Mean } & \multirow{2}{*}{$\begin{array}{c}\text { Std. } \\
\text { Deviation }\end{array}$} & \multirow{2}{*}{$\begin{array}{l}\text { Std. } \\
\text { Error } \\
\text { Mean }\end{array}$} & & \multirow[t]{2}{*}{$\mathbf{F}$} & \multirow[t]{2}{*}{ Sig. } & \multirow[t]{2}{*}{ Mean } & \multirow[t]{2}{*}{$t$} & \multirow{2}{*}{$\begin{array}{c}\text { Std. } \\
\text { Deviation }\end{array}$} & \multirow{2}{*}{$\begin{array}{l}\text { Std. } \\
\text { Error } \\
\text { Mean }\end{array}$} & \multicolumn{2}{|c|}{$\begin{array}{l}95 \% \text { Confidence } \\
\text { Interval of the } \\
\text { Difference }\end{array}$} \\
\hline & & & & & & & & & & & & Lower & Upper \\
\hline \multicolumn{14}{|c|}{ Design Stage } \\
\hline $\begin{array}{l}\text { Group A1 } \\
\text { Group B1 }\end{array}$ & $\begin{array}{l}13 \\
10\end{array}$ & $\begin{array}{l}2.77 \\
2.60\end{array}$ & $\begin{array}{l}0.832 \\
1.174\end{array}$ & $\begin{array}{l}0.231 \\
0.371\end{array}$ & $\begin{array}{l}\text { Rainwater harvesting and water } \\
\text { circulation system simulation }\end{array}$ & 0.164 & 0.689 & 2.70 & 13.273 & 0.974 & 0.203 & 2.27 & 3.12 \\
\hline $\begin{array}{l}\text { Group A1 } \\
\text { Group B1 }\end{array}$ & $\begin{array}{l}13 \\
10\end{array}$ & $\begin{array}{l}2.85 \\
2.90\end{array}$ & $\begin{array}{l}0.555 \\
0.994 \\
\end{array}$ & $\begin{array}{l}0.154 \\
0.314\end{array}$ & $\begin{array}{l}\text { Water consumption analysis to optimize } \\
\text { water distribution system }\end{array}$ & 0.027 & 0.870 & 2.87 & 18.178 & 0.757 & 0.158 & 2.54 & 3.20 \\
\hline $\begin{array}{l}\text { Group A1 } \\
\text { Group B1 }\end{array}$ & $\begin{array}{l}13 \\
10\end{array}$ & $\begin{array}{l}2.62 \\
2.70\end{array}$ & $\begin{array}{l}0.650 \\
1.059\end{array}$ & $\begin{array}{l}0.180 \\
0.335\end{array}$ & Catchment potential investigation & 0.056 & 0.815 & 2.65 & 15.294 & 0.832 & 0.173 & 2.29 & 3.01 \\
\hline $\begin{array}{l}\text { Group A1 } \\
\text { Group B1 }\end{array}$ & $\begin{array}{l}13 \\
10\end{array}$ & $\begin{array}{l}3.38 \\
3.20\end{array}$ & $\begin{array}{l}0.650 \\
0.919\end{array}$ & $\begin{array}{l}0.180 \\
0.291\end{array}$ & Optimization of the water grid design & 0.319 & 0.578 & 3.30 & 20.719 & 0.765 & 0.159 & 2.97 & 3.64 \\
\hline \multicolumn{14}{|c|}{ Construction Stage } \\
\hline $\begin{array}{l}\text { Group A2 } \\
\text { Group B2 }\end{array}$ & $\begin{array}{c}9 \\
14\end{array}$ & $\begin{array}{l}3.11 \\
2.71\end{array}$ & $\begin{array}{l}0.782 \\
0.825\end{array}$ & $\begin{array}{l}0.262 \\
0.221\end{array}$ & $\begin{array}{l}\text { Check the water supply, sewage and } \\
\text { rainwater pipe }\end{array}$ & 1.318 & 0.264 & 2.87 & 16.888 & 0.815 & 0.170 & 2.52 & 3.22 \\
\hline $\begin{array}{l}\text { Group A2 } \\
\text { Group B2 }\end{array}$ & $\begin{array}{c}9 \\
14\end{array}$ & $\begin{array}{l}3.56 \\
2.79\end{array}$ & $\begin{array}{l}0.726 \\
0.802\end{array}$ & $\begin{array}{l}0.242 \\
0.214\end{array}$ & $\begin{array}{l}\text { Conduct effective management to reduce } \\
\text { resource waste. }\end{array}$ & 5.420 & 0.030 & $\begin{array}{l}3.56 \\
2.79\end{array}$ & - & - & - & - & - \\
\hline $\begin{array}{l}\text { Group A2 } \\
\text { Group B2 }\end{array}$ & $\begin{array}{c}9 \\
14\end{array}$ & $\begin{array}{l}3.33 \\
2.86\end{array}$ & $\begin{array}{l}1.000 \\
0.949\end{array}$ & $\begin{array}{l}0.333 \\
0.254\end{array}$ & $\begin{array}{l}\text { Simplification of repetitive and needless } \\
\text { construction process }\end{array}$ & 1.323 & 0.263 & 3.04 & 14.955 & 0.976 & 0.204 & 2.62 & 3.47 \\
\hline \multicolumn{14}{|c|}{ Operation Stage } \\
\hline $\begin{array}{l}\text { Group A3 } \\
\text { Group B3 }\end{array}$ & $\begin{array}{c}7 \\
16\end{array}$ & $\begin{array}{l}3.00 \\
3.00\end{array}$ & $\begin{array}{l}0.817 \\
0.894\end{array}$ & $\begin{array}{l}0.309 \\
0.224\end{array}$ & Real-time monitoring of water resource & 0.000 & 1.000 & 3.00 & 16.871 & 0.853 & 0.178 & 2.63 & 3.37 \\
\hline $\begin{array}{l}\text { Group A3 } \\
\text { Group B3 }\end{array}$ & $\begin{array}{c}7 \\
16\end{array}$ & $\begin{array}{l}2.86 \\
2.69\end{array}$ & $\begin{array}{l}0.900 \\
1.078\end{array}$ & $\begin{array}{l}0.340 \\
0.270\end{array}$ & $\begin{array}{l}\text { Combination of BIM with smart } \\
\text { appliances and smart sensors }\end{array}$ & 0.132 & 0.720 & 2.74 & 13.008 & 1.010 & 0.211 & 2.30 & 3.18 \\
\hline
\end{tabular}




\subsection{Obstacles to Applying BIM for Water Saving in Building Projects}

Twelve obstacles to the current development of BIM from the literature review were listed in the questionnaire. As stated in Section 1.3, these obstacles were divided into four clusters: Technical, human, economic, and management factors. Respondents were asked to point out the barriers hindering the use of BIM in the water efficiency project, their results are shown in Table 6. In order to obtain the key factors hindering the development of BIM, and provide a reference for future research, data was processed through the hypothesis testing method. The hypothesis testing results are shown in Table 7. A 95\% confidence interval of the difference is adopted. Those factors with respondents agreeing over the lower limit value such as the BIM software is still in progress, lack of BIM talent, reliance on traditional methods, high short-term cost, difficulties in managing change, difficulties in business process transformation are main obstacles hindering the development of BIM in water efficiency.

Table 6. The response of obstacles.

\begin{tabular}{ccc}
\hline General Aspects & Obstacle & Respondents Agreeing \\
\hline \multirow{3}{*}{ Technical factor } & Poor adaptability of BIM technology & $21.74 \%$ \\
& High technical difficulty & $26.09 \%$ \\
& BIM software is still in progress & $47.83 \%$ \\
\hline \multirow{2}{*}{ Human factor } & Lack of the structure of knowledge and ability & $52.17 \%$ \\
& Lack of BIM talent & $43.48 \%$ \\
\hline \multirow{2}{*}{ Economic factor } & Rely on traditional methods & $52.17 \%$ \\
& High short-term cost & $47.83 \%$ \\
& Long payback period & $30.43 \%$ \\
Management factor & Untapped BIM market & $30.43 \%$ \\
& Difficulties in managing change & $47.83 \%$ \\
& Low acceptance in management & $17.39 \%$ \\
\hline
\end{tabular}

Table 7. Hypothesis testing results of BIM obstacles (questionnaire's response).

\begin{tabular}{cccccccc}
\hline Item & $\mathbf{N}$ & Mean & $\begin{array}{c}\text { Std. } \\
\text { Deviation }\end{array}$ & $\begin{array}{c}\text { Std. Error } \\
\text { Mean }\end{array}$ & $t$ & \multicolumn{2}{c}{$\begin{array}{c}\text { 55\% Confidence } \\
\text { Interval of the } \\
\text { Difference }\end{array}$} \\
\hline Obstacle & 12 & $38.77 \%$ & 0.126 & 0.036 & 10.627 & $30.74 \%$ & \multicolumn{2}{c}{$40.80 \%$} \\
\hline
\end{tabular}

\subsection{Results of Interviews}

The interviewees were firstly asked to supplement the BIM-enhanced construction activities and give suggestions for using BIM in water efficiency. Architect A stated that both consulting companies as well as architect companies consider that the only purpose of using BIM is to meet government policies and simply check clash detection at the current stage. Architect B stated that the current application of BIM for building water efficiency should take more consideration of the effect of BIM throughout the entire building life cycle. For example, BIM provides a platform for designers, constructors and owners to achieve an effective collaboration and communication. Architect D proposes to combine BIM with sponge city strategy [39] to facilitate access to the BIM model of the municipal pipeline, which in turn facilitates the utilization by the owner units, and four interviewees agreed that the integration of BIM and sponge city strategy is a future research-worthy topic about water efficiency.

The interviewees were then asked to supplement their views on how to address the obstacles to the application of BIM in water efficiency. Three interviewees stated that in the current market environment, BIM technology means that a large amount of input but with lower output, which also hinders some companies from investing in BIM. Based on the variety of obstacles, Architect $C$ from the 
construction unit stated that in the short term, some construction companies in China would not invest in BIM and building water efficiency technologies. Those new items from interviews are regarded as supplements to the questionnaire, and both of them are contributed to the framework development.

\section{BIM-based Water Efficiency (BWe) Framework Development}

A preliminary BIM-based building water efficiency framework (BWe framework) was developed based on the findings of this research. The BWe framework divides the building life cycle into three stages: Design stage, construction stage and operation stage. It encompasses water efficiency requirements, the implementation of water efficiency measures and BIM-aided collaborative communication throughout the design, construction and operation stages. The framework development flow chart is shown in Figure 2.

As shown in Figure 3, the BWe framework addresses some common problems during a BIM-aided construction project, and the potential methods of BIM's application in water efficiency, which are numbered and listed in Table 8.

Table 8. The conclusion of numbered items.

\begin{tabular}{|c|c|}
\hline Code & Content \\
\hline A1 & Requirements: Set water efficiency goals [1-10] \\
\hline A2 & $\begin{array}{l}\text { Problem: Ineffective design due to ineffective communication between different professionals } \\
\text { (architect, structural engineer, water-electrical designer) [35] }\end{array}$ \\
\hline A3 & Problem: Ineffective design due to various interventions (from constructor, Proprietor) [37] \\
\hline A4 & Promote the use of water efficiency appliances $[40,41]$ \\
\hline A5 & Promote the application of advanced water supply facilities [40] \\
\hline A6 & Problem: The lack of feasibility researches of BIM's application in building water efficiency [24] \\
\hline A7 & Measure: Use BIM engine to simulation rainwater harvesting and water cycle system $[18,24]$ \\
\hline A8 & $\begin{array}{l}\text { Measure: Use BIM engine to analyze the water consumption and optimize the water } \\
\text { distribution system [15] }\end{array}$ \\
\hline A9 & Measure: Use BIM engine to investigate catchment potential [27] \\
\hline A10 & Measure: Use BIM to optimize the design of water grid [42] \\
\hline $\mathrm{B} 1, \mathrm{C} 1$ & $\begin{array}{l}\text { Problem: During data exchange from design stage to construction stage and to operation stage, } \\
\text { data loss may occur and the targets set in previous stage are neglected in the current stage [19] }\end{array}$ \\
\hline B3 & $\begin{array}{c}\text { Measure: Simplify some repetitive and unnecessary construction procedure through BIM, then } \\
\text { saving water, energy and cost [19] }\end{array}$ \\
\hline B4, B5, B6 & Measure: Check the water supply, sewage and rainwater pipe [32] \\
\hline $\mathrm{C} 2$ & Measure: Real-time monitoring of resource such as electricity, water and gas [30] \\
\hline C3 & Measure: Set up specifications for water use components (such as taps, kitchen, washing) [3-5] \\
\hline $\mathrm{C} 4$ & Measure: Combine BIM with smart appliances and smart sensors [33] \\
\hline C5 & Measure: The monitoring of water consumption and leak detection through BIM $[33,40]$ \\
\hline
\end{tabular}




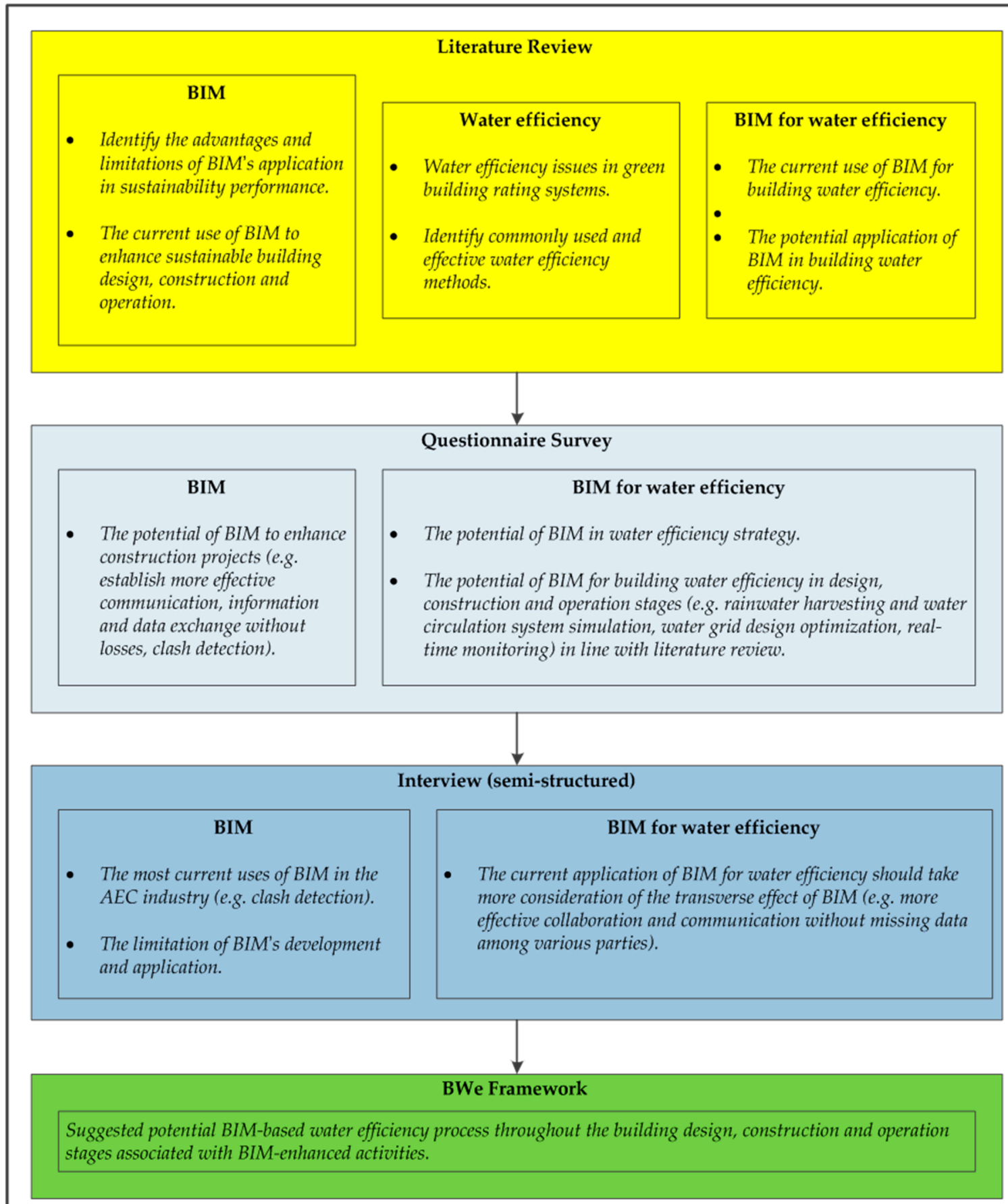

Figure 2. The BWe framework development flow chart. 


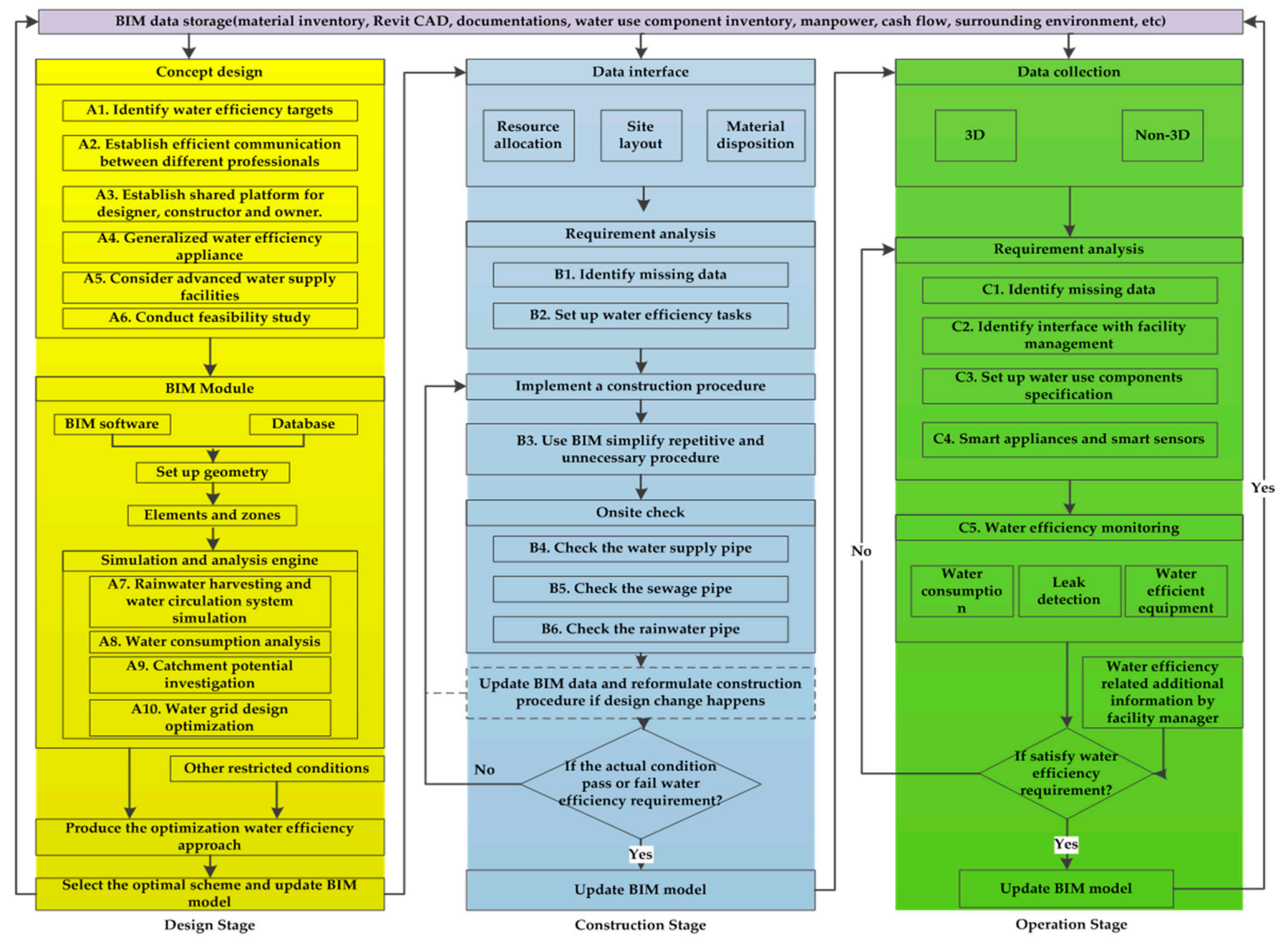

Figure 3. Preliminary BWe framework.

\subsection{Design Stage}

As shown in Figure 3, the design stage mentioned in the BWe framework is divided into two parts: The concept design and BIM module. The part of concept design mainly aims at the common problems that many engineers may encounter during project implementation, and proposes corresponding BIM-aided improvement measures or solutions. These problems have been listed in Table 8. For example, for the problem of ineffective design due to various interventions and inadequate communication among project parties, BIM provides a shared platform for designers, constructors and owners. For the problem of a lack of feasibility researches of BIM's application in water efficiency, feasibility studies are conducted before technical design. Moreover, in response to the suggestions on water efficiency items from various green building rating systems, the adoption of water efficiency appliance and advanced water supply facilities is extended as well.

For the BIM module, the 3D model should be established through the combined use of both BIM software and database. According to the results of the questionnaire analysis, the integration of BIM and four water efficiency measures during the design stage is beneficial to achieve building water efficiency targets more effectively: Rainwater harvesting and water circulation system simulation, water consumption analysis to optimize the water distribution system, catchment potential investigation, and water grid design optimization.

\subsection{Construction Stage}

According to the results of interviews, the application of BIM technology during the construction stage can firstly help conduct effective management to resource allocation, site layout and materials for each part and then reduce resource waste. During the data exchange from the design stage to the construction stage, it is possible that data loss may be involved. For example, the targets or 
requirements set in design and construction stages are neglected in the operation stage. So it is important to identify missing data in order that the water efficiency performance set in the previous stages can be achieved eventually. Compared with the tradition workflow, BIM can also simplify some repetitive and unnecessary construction procedure after the construction procedure is formulated, thereby resources like water, energy and cost could be reduced. After the optimization of the construction procedure, the onsite checks should take measures to avoid water wastage. As shown in Figure 3, the onsite checks for water supply, sewage and rainwater can be more effectively conducted with the assistance of BIM.

However, over $65 \%$ of questionnaire respondents indicate that they have encountered problems such as rework caused by design change, which is a common but non-negligible phenomenon during the construction stage. Therefore, if design change happens, BIM data should be updated firstly and the construction procedure can be reformulated when necessary.

\subsection{Operation Stage}

All the questionnaire respondents believe that BIM can help integrate the building information produced in the previous stages with the current stage information. So the first step for water efficiency in the operation stage should be identifying the missing data. As shown in the "Requirement Analysis" in Figure 3, in response to the green building rating systems, the water use components specification, such as taps, showers and washing machines can be set to achieve better monitoring of water consumption. Additionally, as the development and increasing implement of smart appliances and smart sensors, some researches attempted to combine BIM with these products [12], and the feasibility is verified through the questionnaire in this study: Over $91 \%$ of respondents believe that it does have the potential.

After the requirement analysis is complete, the water efficiency monitoring is conducted throughout the whole operation stage from three aspects: Water consumption, leak detection and water efficient equipment. Water efficiency related additional information by facility managers is considered as well.

\subsection{Establishment of Conceptual Algorithm}

Based on the BWe framework and the numbered items, a conceptual algorithm with a summation formula is established to supplement explorative building water efficiency research with quantitative content. The formula (1) is closely coupled with the BWe framework and is applied in the last step of each building stage to predict the effectiveness of water efficiency. The item values and the coefficients in the equation may vary according to actual construction projects. The total score could reflect the effectiveness throughout the whole design, construction and operation stages.

$$
S C=\sum_{\substack{i=1, j=1, k=1}}^{n}\left(\alpha_{D e} A_{i}+\alpha_{c o n} B_{j}+\alpha_{o} C_{k}\right)
$$

- $\quad$ SC: The total score marked through the process of BWe framework;

- $\alpha_{D e}$ : The influence coefficient for the design stage;

- $A_{i}$ : The water efficiency items during the design stage;

- $\alpha_{c o n}$ : The influence coefficient for the construction stage;

- $B_{j}$ : The water efficiency items during the construction stage;

- $\alpha_{0}$ : The influence coefficient for the operation stage;

- $C_{k}$ : The water efficiency items during the operation stage. 


\section{Verification}

\subsection{The Results from Interviews}

The preliminary BWe framework and the conceptual formula are then verified by four experienced architects from the respondents of the early questionnaire and one professor with abundant research experience in the field of green building. The interviewees were asked to use the grade $1-4(1=$ Strongly disagree, 2 = disagree, 3 = agree, 4 = strongly agree) to assess the clarity, structure intelligibility, implementation feasibility of the BWe framework and formula. As shown in Table 9, the preliminary BWe framework and the conceptual formula are proved to be effective in the combination of BIM and water efficiency.

Table 9. The score of the BWe framework and formula by interviewees.

\begin{tabular}{cc}
\hline The Evaluation Criteria & Mean Value \\
\hline The preliminary BWe framework & \\
\hline The structure of the framework is clear and fluent. & 3.6 \\
The contents of framework are reasonable and appropriate. & 3.0 \\
The framework has implementation feasibility and operability. & 3.0 \\
\hline \multicolumn{2}{c}{ The conceptual formula } \\
\hline The formula is reasonable and easy to implement. & 3.2 \\
The formula has implementation feasibility. & 3.0 \\
The formula is closely coupled with the BWe framework. & 3.6 \\
\hline
\end{tabular}

The respondents were asked to suggest improvements to the conceptual formula. All the respondents agreed that the formula is closely coupled with the BWe framework, one of the respondents suggested that further research on the determination of formula coefficients could be extended beyond this study.

Respondents were then asked to identify the most important factor of water efficiency at each stage, state the limitations in current water efficiency methods and corresponding BIM-based improvements. Two respondents stated that the feasible application scheme study of BIM in building water efficiency should start from the advantages of BIM compared to other tools such as tradition water gird design software and maximize its advantages. In the design phase, the simulation of rainwater harvesting and utilization systems and the optimization of the water pipe network (water supply, sewage and rainwater pipeline system) design are considered to be two main research directions for BIM in water efficiency. Two interviewed architects stated that when designing rainwater catch pits in many current green buildings in China, designers use the estimated value or empirical data of annual rainwater collection volume and recycling dosage to assist in the design, which brings the negative consequences that the design model is highly idealistic and the computational results are inaccurate compared to the actual situation. For example, in actual projects, the collected rainwater exceeds the demand for use and overflows from the rainwater catch pits during the rainy season, while running water compensation is adopted without sufficient rainwater during the dry season. However, due to the over-idealization of the model during the estimation process, the difference between the rainy season and the dry season has been balanced, which tend to cause the aftermath that the actual situation during operation cannot meet the water efficiency goals set in the design stage. Four out of five of the respondents agreed that BIM can help conduct dynamic real-time monitoring of annual precipitation in the area where the building is located, so the maximum non-conventional water use of the project is simulated and forecasted through BIM tools. Based on the results of monitoring and simulation, rainwater is collected and utilized more rationally through the formulation of regulation and storage equipment scheme, and further achieved the goal of water efficiency. Such a BIM-based dynamic monitoring method replaces the previous solid-state estimation method, which provides architects with new references and new inspiration. Two architects also state that when designing the water pipe 
network of green buildings, it is necessary to set pressure reducing valves so that the water pressure can be controlled not to be excessive, which also brings about an increase in cost. It is also an effective measure can be conducted through BIM that optimizing the water pipe network design to minimize the quantities of pressure reducing valves even when there is a high municipal water pressure. In addition, four out of five of respondents believe that some water harvesting, storage and pipe network design measures of "the Sponge City" management concept are of great reference value in this study.

One of the respondents further stated that some construction companies are optimistic about the potential of BIM because BIM is able to conduct clash detection accurately and efficiently. In the traditional design, designers of architecture, structure, and equipment draw their own drawings separately, and the omission of docking among various professions is difficult to be avoided. In addition, when occasional slight design changes occur at the construction site, it is possible that some of the professions have completed the changes while others have not, which leads to the occurrence of pipe network collisions during construction.

In the operation phase, all of the respondents agree that BIM has a positive effect on water leak detection. This can be combined with smart sensors to identify leaks rapidly and perform maintenance through changes of pipeline pressure. Therefore, many mainstream green building rating systems worldwide advocate setting up water meters as comprehensively as possible. Three out of five of the respondents believe that BIM can be integrated with some large energy monitoring software or smart appliances to conduct real-time monitoring for the water consumption of various water use components in and generate monitoring reports related to human behavior pattern such as the annual water consumption and the water use frequency.

\subsection{The Updated BWe Framework}

Respondents were asked to suggest improvements to the BWe framework. In the design stage, one of the interviewees suggested that the successive logical relationship from water consumption analysis to the water grid design optimization could be set for BIM's simulation and analysis module. Integrating the suggestions from interviewees, the procedure of the adjustment if design change happens in the construction stage, is described in more detail to emphasize the advantages of BIM in clash detection. While in the operation stage, one of the participating architects suggested that the recycling dosage of rainwater and reclaimed water could be added to the items of water efficiency monitoring to evaluate the effectiveness of rainwater reuse and reclaimed water recycling system. These improvement items are listed in Table 10 with respective codes. Based on the suggestions provided by the respondents, the BWe framework has been revised, which is shown in Figure 4.

Table 10. The conclusion of improvement items for BWe framework.

\begin{tabular}{cr}
\hline Code & Content \\
A7-A10 & $\begin{array}{r}\text { The successive logical relationship is set for BIM's simulation and analysis module } \\
\text { (Water consumption analysis, catchment potential investigation, rainwater harvesting and } \\
\text { water cycle system simulation, water grid design optimization). }\end{array}$ \\
\hline B5 & $\begin{array}{r}\text { The procedure of the adjustment if design change happens is described in more detail to } \\
\text { emphasize the advantages of BIM in clash detection. }\end{array}$ \\
\hline C5 & The monitoring of recycling dosage is added. \\
\hline
\end{tabular}




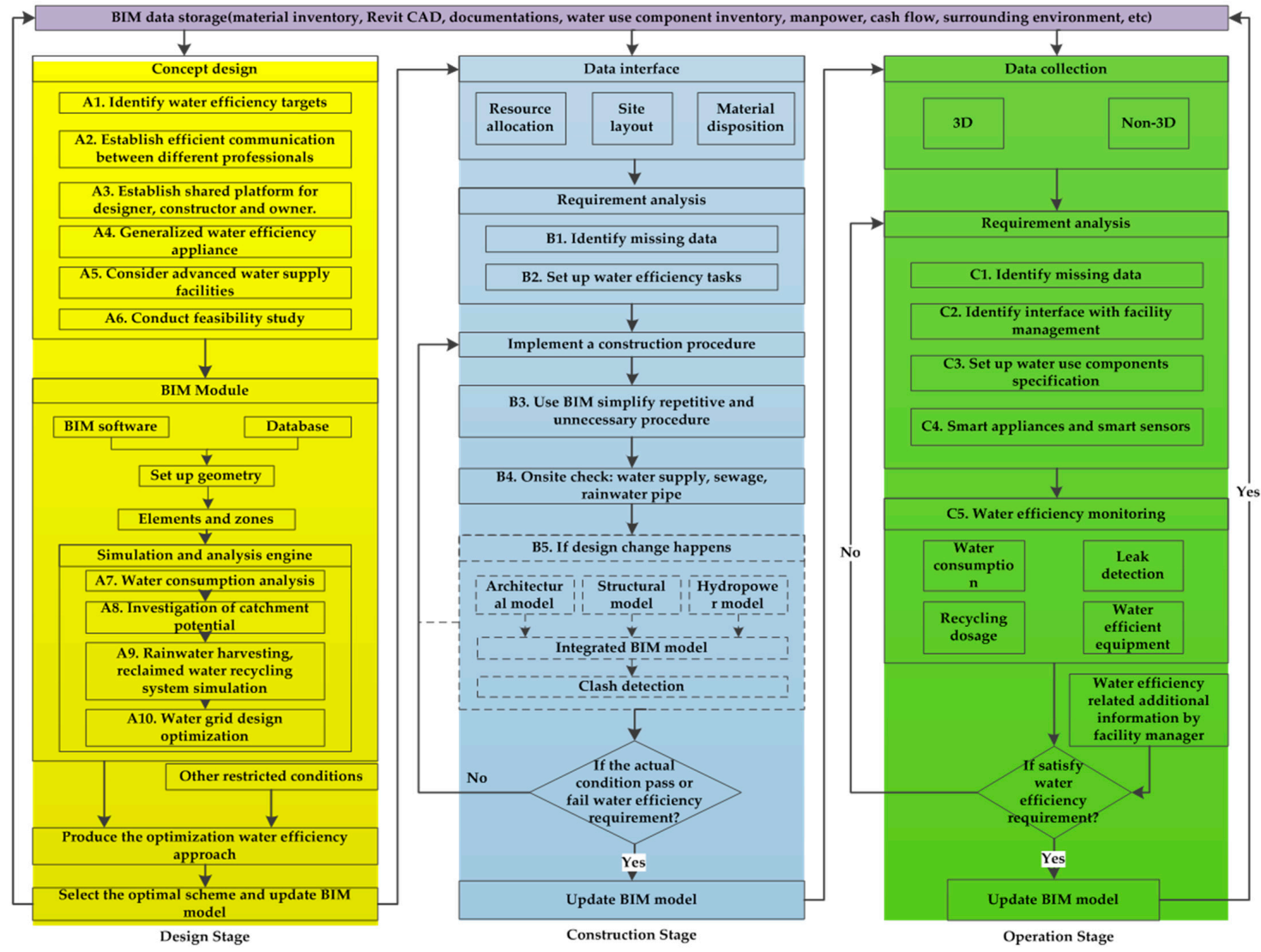

Figure 4. The updated BWe framework in line with validation results.

\section{Discussion and Conclusions}

With the increasing attention paid to building water efficiency and the promotion of BIM technology by the AEC industry, the advantages of BIM including enhanced collaboration among various parties [14,15,35], improved work efficiency [36], simulation and analysis of sustainability performance $[17,18]$ are gradually accepted. In a newest BIM report published by NBS (National Building Specification) in 2018 [13], 65\% of respondents believe that BIM is beneficial to improve time efficiency, 79\% BIM users being surveyed agree that adopting BIM increases coordination of construction documents. In another BIM industry report analyzing the Chinese AEC industry market from 2016 to 2017 [43], BIM means an integration of visibility, coordination, simulation, optimization and graphical, thereby it is able to greatly improve design efficiency. The results of such industry reports are in line with the findings of this study.

In this study, the BWe framework is established to provide reference for the application of BIM in water efficiency. However, it still has limitations. For example, the sample size could only support tentative research and the statistical significance is limited; the actual operation of the framework is lack of verification by case studies, and technical components of the BWe framework need to be researched individually in further studies. More detailed research and engineering case studies are required in order to apply BIM to building water efficiency more effectively. The BIM guidance for Water Industry [25] proactively forecasts the transition to a Digital Built Water and Waste Water framework, which delivers high performing assets. Based on the extensive literature review, the results of the questionnaire survey, and the results of interviews with experienced practitioners, this publication attempts to propose several potential research directions below: 
1. BIM and rainwater harvesting and reuse system

Using BIM tools to conduct dynamical monitoring of annual precipitation in the area where the building is located. Based on the result of dynamic monitoring, the simulation and prediction of the largest nontraditional water of the project is able to be achieved through BIM technologies and the guidelines for the regulation and storage facilities can be formulated. Thereby rainwater is able to be collected and utilized more reasonably and the difference between the dry season and the rainy season can be balanced.

\section{BIM and the optimization of pipeline design}

For a specific sustainable building project, visualize the water pipeline design through BIM during the design stage to avoid construction collisions. In addition, based on the given municipal water pressure, optimize the pipeline direction through the BIM tools, and minimize the use of the pressure reducing valves in accordance with the requirements of informal water pressure.

3. BIM and real-time monitoring of water use

For the operation stage of a specific sustainable building project, the water use appliances are classified into detailed types and the real-time monitoring of water consumption of each type can be conducted through the combined utilization of BIM and intelligent sensors. Based on the real-time monitoring results, human behavior patterns of water use can be summarized and then propose corresponding water efficiency measures.

4. BIM and saving of hot water

Conducting simulation and analysis of solar water heater through BIM tools and balancing the heating efficiency between summer and winter to achieve the goals of saving hot water and energy efficiency, which would bring greater economic benefits as well.

Author Contributions: Conceptualization, Z.L. and C.Z.; Methodology, Z.L. and M.O.; Software, C.Z.; Validation, C.Z., Z.L. and Y.G.; Formal analysis, C.Z.; Investigation, C.Z.; Resources, Y.G.; Data curation, Z.L.; Writing-original draft preparation, C.Z.; Writing-review and editing, Z.L., Y.G., M.O. and P.D.; Visualization, C.Z.; Supervision, Z.L.; Project administration, Z.L.; Funding acquisition, Z.L.

Funding: This research was funded by South China University of Technology, Guangzhou, China, grant number x2sj/K5180600.

Acknowledgments: In the paper completed, I would like to express my deep respect and gratitude to all who have helped me with this study. Thanks to all architects in the AEC industry that responded to the questionnaire survey and interview, and provided a lot of valuable suggestions and guidance. So that the framework of BIM's application in water efficiency is able to be developed and this paper is able to be finished.

Conflicts of Interest: The authors declare no conflict of interest. The funders had no role in the design of the study; in the collection, analyses, or interpretation of data; in the writing of the manuscript, or in the decision to publish the results.

\section{References}

1. USGBC. LEED for Building Design and Construction; Version 4; U.S. Green Building Council: Washington, WA, USA, 2018.

2. USGBC. LEED for Building Operations and Maintenance; Version 4; U.S. Green Building Council: Washington, WA, USA, 2018.

3. SD233-2.0:2016. BREEAM International New Construction 2016. Available online: http://www.breeam.com (accessed on 28 April 2019).

4. SD221-2.0:2015. BREEAM In-Use International. Available online: http://www.breeam.com (accessed on 28 April 2019).

5. SD5078: BREEAM UK New Construction 2018. 1.0. Available online: http://www.breeam.com (accessed on 28 April 2019). 
6. BCA Singapore. Green Mark for Residential Buildings: 2016 Criteria. Available online: https://www.bca.gov. sg/ (accessed on 28 April 2019).

7. BCA Singapore. Green Mark for Non-Residential Buildings NRB: 2015. Available online: https://www.bca. gov.sg/ (accessed on 28 April 2019).

8. Hong Kong Green Building Council, BEAM Plus New Buildings: 2012. Version 1.2. Available online: https://www.hkgbc.org.hk/eng/BPRef-manuals_assessment.aspx (accessed on 28 April 2019).

9. Hong Kong Green Building Council, BEAM Plus Existing Buildings: 2016. Version 2.0. Available online: https://www.hkgbc.org.hk/eng/BPRef-manuals_assessment.aspx (accessed on 28 April 2019).

10. MOHURD. GB/T50378-2014. China's Assessment Standard for Green Building; Ministry of Housing and Urban-Rural Development of the People's Republic of China: Beijing, China, 2014.

11. He, F. World Green Buildings: Trends and Standards. Constr. Sci. Technol. 2005, 6, 34-35.

12. Maltese, S.; Tagliabue, L.C.; Cecconi, F.R. Sustainability assessment through green BIM for environmental, social and economic efficiency. Procedia Eng. 2017, 180, 520-530. [CrossRef]

13. NBS. NBS National BIM Report 2018. Available online: https://www.thenbs.com/knowledge/the-nationalbim-report-2018 (accessed on 28 April 2019).

14. Liu, Z.; Osmani, M.; Demian, P.; Baldwin, A. A BIM-aided Construction Waste Minimisation Framework. Autom. Constr. 2015, 59, 1-23. [CrossRef]

15. Lu, Y.; Wu, Z.; Chang, R.; Li, Y. Building Information Modeling (BIM) for green buildings: A critical review and future directions. Autom. Constr. 2017, 83, 134-148. [CrossRef]

16. Fadeyi, M.O. The role of Building Information Modeling(BIM) in delivering the sustainable building value. Int. J. Sustain. Built Environ. 2017, 6, 711-722. [CrossRef]

17. Li, B.; Zhang, J.; Liu, J.; Lu, Y. Study and Application of Architecture Sustainable Design Methodology Based on BIM. J. Green Intell. 2015, 3, 67-71.

18. Bonenberg, W.; Wei, X. Green BIM in sustainable infrastructure. Procedia Manuf. 2015, 3, 1654-1659. [CrossRef]

19. Liu, Y. Application of BIM technology in green construction of construction engineering. Eng. Technol. Appl. 2018, 1, 70-71.

20. Ji, B.; Qi, Z.; Jin, Z. BIM Technology Application in Construction Operation Management Research-Taking the Olympic Village Project as an Example. J. Pku. Civ. Eng. Arch. 2014, 1, 68-72.

21. Chen, L.; Pan, W. BIM-aided variable fuzzy multi-criteria decision making of low-carbon building measures selection. Suatain. Cities Soc. 2016, 27, 222-232. [CrossRef]

22. Lim, Y.W. BIM-based Sustainable Building Design Process and Decision-making. In Proceedings of the 2017 International Conference on Research and Innovation in Information Systems (ICRIIS), Langkawi, Malaysia, 16-17 July 2017.

23. Olawumi, T.; Chan, D. Identifying and prioritizing the benefits of integrating BIM and sustainability practices in construction projects: A Delphi survey of international experts. Sustain. Cities Soc. 2018, 40, 16-27. [CrossRef]

24. Bernstein, H.; Jones, S.; Russo, M. Green BIM-How Building Information Modeling is contributing to green design and construction. J. Inf. Technol. Civ. Eng. Arch. 2015, 2, 20-36.

25. British Water. BIM4Water Owner Operator Guidance Document; V5.2.1; British Water: London, UK, 2017.

26. Bsi.BIM Level 2 Standards. Available online: https://bim-level2.org/en/standards/ (accessed on 28 April 2019).

27. Wong, J.K.W. Enhancing Environmental Sustainability over building life cycles through GREEN BIM: A review. Autom. Constr. 2015, 57, 156-165. [CrossRef]

28. Martins, J.P.; Monteiro, A. LicA: A BIM based automated code-checking application for water distribution systems. Autom. Constr. 2013, 29, 12-23. [CrossRef]

29. Edmondson, V.; Cerny, M.; Lim, M. A smart sewer asset information model to enable an 'Internet of Things' for operational wastewater management. Autom. Constr. 2018, 91, 193-205. [CrossRef]

30. Motawa, I.; Carter, K. Sustainable BIM-based Evaluation of Buildings. Procedia Soc. Behav. Sci. 2013, 74, 419-428. [CrossRef]

31. Wei, T.; Chen, G.; Wang, J. Application of BIM Technology in Building Water Supply and Drainage Design. IOP Conf.Ser. Earth Environ. 2017. [CrossRef]

32. Jia, J.; Sun, J.; Wong, Z. The construction of BIM application value system for residential buildings' design stage in China based on traditional DBB mode. Procedia Eng. 2017, 180, 851-858. [CrossRef] 
33. Howell, S.; Rezgui, Y.; Beach, T. Integrating building and urban semantics to empower smart water solutions. Autom. Constr. 2017, 81, 434-448. [CrossRef]

34. Ahuja, R.; Sawhney, A.; Arif, M. Driving lean and green project outcomes using BIM A qualitative comparative analysis. Int. J. Sustain. Built Environ. 2017, 6, 69-80. [CrossRef]

35. Abaglo, A.J.; Bonalda, C.; Pertusa, E. Environmental Digital Model: Integration of BIM into environmental building simulations. Energy Procedia. 2017, 122, 1063-1068. [CrossRef]

36. Li, Z. Application of BIM in building sustainable design. J. Sustain. Nat. Sci. 2012, 2, 68-71.

37. Walasek, D.; Barszcz, A. Analysis of the adoption rate of BIM and its return on investment. Procedia Eng. 2017, 172, 1227-1234. [CrossRef]

38. Ustinovichius, L.; Popov, V.; Cepurnaite, J.; Vilutienè, T.; Samofalov, M.; Miedziałowski, C. BIM-based process management model for building design and refurbishment. Arch. Civ. Mech. Eng. 2018, 4, 1136-1149. [CrossRef]

39. Nguyen, T.T.; Ngo, H.H.; Guo, W.; Wang, X.C.; Ren, N.; Li, G.; Ding, J.; Liang, H. Implementation of a specific urban water management-Sponge City. Sci. Total Environ. 2019, 652, 147-162. [CrossRef]

40. Wong, G.Y. The causes of water supply and drainage waste and water efficiency measures. China Sci. Technol. Inf. 2014, 19, 33-34.

41. Wong, X.N. The roots of domestic water waste during the process of urbanization in China. J. Arid Land Resour. Environ. 2015, 11, 49-54.

42. Yu, G.S. Research and Application of BIM Technology in The Design of Pipe Network Synthesis. Master's Thesis, Dalian University of Technology, Dalian, China, 2016.

43. Zhongjian Zhengyan. The Report for BIM Industry Development in China 2016. Available online: http://www.360doc.com/content/16/1119/18/30514273_607803288.shtml (accessed on 28 April 2019).

(C) 2019 by the authors. Licensee MDPI, Basel, Switzerland. This article is an open access article distributed under the terms and conditions of the Creative Commons Attribution (CC BY) license (http://creativecommons.org/licenses/by/4.0/). 